\title{
HUGO BIANCHY E A FORMAÇÃO EM DANÇA NA CIDADE DE FORTALEZA
}

\author{
J. A. M. DE SALES; J. R. PEIXOTO; T. M. DE S. FRANÇA; G. DE A. ARRAIS \\ Universidade Estadual do Ceará - UECE \\ albio.sales@uece.br
}

Submetido 03/03/2015 - Aceito 02/02/2017

DOI: $10.15628 /$ holos.2017.2818

\section{RESUMO}

Este é um estudo sobre a formação docente em dança na cidade de Fortaleza, a partir da contribuição do bailarino e professor Hugo Bianchy, nas décadas de 1950 e 1960. Trata-se de uma pesquisa histórica, na qual utilizamos como base metodológica os conceitos da Nova História Cultural (NHC). Utilizamos também procedimentos da História Oral. Deste modo, para a coleta de informações adequadas à compreensão desta pesquisa, utilizamos fontes orais, iconográficas e publicações do Jornal O Povo. O estudo mostra que a formação em dança na cidade de Fortaleza tem como marco cronológico a década de 1960, quando Hugo Bianchy criou sua academia de dança. Os dados da pesquisa mostram que nesta fase inicial ainda não existia uma preocupação com a formação do professor de dança, e sim, com a formação do artista bailarino.

PALAVRAS-CHAVE: formação docente, dança, Hugo Bianchy, história da arte.

\section{HUGO BIANCHY AND THE FORMATION IN DANCE IN THE CITY OF FORTALEZA}

\section{ABSTRACT}

This is a study of teacher training in dance in the city of Fortaleza from the contribution of Hugo Bianchy dancer and teacher in the 1950s and 1960s. It is a historical research on which we used as a methodological basis the concepts of the New Cultural History (NHC). We also use oral history procedures. Thus, for the collection of information for the understanding of this research, we used oral sources, iconographic and publications on the newspaper The People. The study shows that the dance training in Fortaleza is marked by the 1960s, when Hugo Bianchy deploys her dance academy. We also noticed that there was a concern with the formation of a dance teacher, and yes, with the formation of the artist dancer.

KEYWORDS: teacher training, dance, Hugo Bianchy, art history. 


\section{INTRODUÇÃO}

Um dos problemas enfrentados pelos que trabalham com o ensino de Arte no Brasil, especialmente nos estados do Norte e Nordeste, tem sido a reduzida quantidade de publicações sobre a produção artística local disponível. No Ceará, algumas linguagens artísticas, como as Artes Visuais e o Teatro, possuem em seus quadros pessoas que se preocupam em escrever sobre a memória de sua geração, publicando documentos que nos aproximam dos fenômenos e processos formativos que vivenciaram.

Sobre a dança faltou alguém que exercesse essa função, ficando para a nova geração de pesquisadores e historiadores a tarefa de trazer para a atualidade essas memórias e construir uma história da dança no Ceará, para que professores e alunos da atualidade possam compreendê-la numa perspectiva histórica, tendo por base os fatos e sujeitos locais. Trata-se de uma tarefa necessária, entretanto, não é trabalho fácil, pois nem sempre dispomos de documentos, e algumas vezes, esta falta está relacionada às características dos processos de produção desta arte, que possui poucos registros gráficos de seus processos de criação e menos ainda das apresentações.

Ao penetrar o universo da dança percebe-se a quantidade de performances e técnicas que se perderam no tempo, porque ficaram apenas na memória daqueles que a produziram e dos espectadores. Os folhetos, programas e catálogos das apresentações fornecem apenas nomes de bailarinos, músicas e alguns dados sobre a formação. São necessários também de dados sobre os processos de composição da cena e construção coreográfica. Tais elementos podem nos conduzir a um olhar mais apurado do fenômeno para a sua compreensão, numa perspectiva histórica.

Vale ressaltar que a escassez de registros não é uma característica exclusiva da linguagem dança, visto que o problema de falta de textos históricos elaborados com criticidade e critérios acadêmicos é comum a praticamente todas as linguagens artísticas. Com base nesta problemática, os autores do presente texto, buscando discutir os processos formativos da dança em Fortaleza, numa perspectiva histórica, apresentam a trajetória de Hugo Bianchy no início da primeira metade do século XX.

Dentro deste recorte temporal e espacial da história da dança na cidade de Fortaleza encontramos como principal personagem o bailarino e professor Hugo Bianchy, que é agente aglutinador de inciativas neste campo.

Nesse sentido, a relevância desta pesquisa pode ser creditada ao esforço dos autores em buscar uma compreensão de processos formativos envolvidos na trajetória de Hugo Bianchy e da sua atuação como formador de formadores, no âmbito da dança cênica em Fortaleza.

Vivemos um momento da história do ensino de Arte no Ceará, no qual a dança torna-se fenômeno presente na formação de professores, embora os cursos de formação ainda estejam distantes de atender as demandas de profissionais para a educação básica. Paralelo a isso, temos uma produção de dança que conduz a movimentos de discussões sobre processos contemporâneos, como um lugar de abordagens e enfoques diferenciados. Todas essas dificuldades encontradas na relação entre produção e reflexão conduzem-nos a discussões sobre 
o processo de formação em dança, bem como a necessidade de pesquisas e sistematização destas sobre a temática.

A questão central da presente investigação é discutir formação docente em dança na cidade de Fortaleza, a partir das contribuições do bailarino e professor Hugo Bianchy. Como perguntas orientadoras da investigação elegem-se as seguintes: como se deu e quais as características do processo formativo e formador do bailarino e professor Hugo Bianchy na cidade de Fortaleza nas décadas de 1950 e 1960? O que se pode identificar e caracterizar como elementos de formação em dança no discurso de Hugo Bianchy?

\section{REVISÃO BIBLIOGRÁFICA}

\subsection{0 campo da dança como profissão}

O que se compreende hoje como campo da dança é algo que pode ser definido a partir do conceito de "campo artístico" elaborado por Bourdieu. (2010, p. 261-262) Para ele, o campo é "uma rede de relações objetivas (de dominação ou de subordinação, de complementaridade ou de antagonismo etc.) entre posições", na qual o "espaço das posições tende a comandar o espaço das tomadas de posições", dentro da qual concorrem instituições e indivíduos pelo controle do monopólio em relação à autoridade artística, levando o campo a adquirir autonomia perante os poderes econômicos, políticos e burocráticos. Sob esse aspecto, o que se entende por campo da dança é algo que se consolida a partir de códigos e regras próprios de seus pares, que reproduzem elementos desta linguagem artística por meio de um habitus, constituído por um sistema de práticas incorporadas aos sujeitos.

Como aconteceu com a maioria das linguagens artísticas foi somente no século XIX que a dança passou a ser vista como profissão. Surge na Europa nas cortes da Itália renascentista durante o século XV com o Balett, cujo desenvolvimento se deu principalmente na Inglaterra, Rússia e França e de lá se expandiu para as Américas. Foi através dos balés da corte (apresentações realizadas por nobres com o intuito de promover o entretenimento destes), que a dança saiu "[...] dos palácios para o palco dos teatros, introduzindo um crescente número de dançarinos profissionais nos espetáculos". (MENDES, 2001, p. 28)

Enquanto campo pode se dizer que a dança se constituiu na Europa, no período romântico (Século XIX), época em que se inicia a oferta de espetáculos para o público pagante, em sua maioria composto por uma burguesia emergente. Outro dado importante do período foi o reconhecimento da presença feminina no balett. Fato atribuído ao trabalho de Maria Taglioni, bailarina sueca que viveu de 1804 a 1884 e se apresentou nas principais cidades da Europa. As mais importantes mudanças introduzidas por Taglioni foram o uso de uma sapatilha especial, para a execução de movimentos, que hoje se conhece como "pontas" e o uso de saias mais curtas, valorizando as pernas. Sua forma feminina, delicada e esguia ao dançar, também tornouse um padrão para as bailarinas. (KASSING, 2007)

Embora algumas formas de dança sempre estivessem presentes no cotidiano do brasileiro, através das festas bailes e das manifestações folclóricas, foi somente em fins de 1930 que a "dança cênica" representada especialmente pelo ballet, passou a ser reconhecida como uma atividade artística autônoma no Brasil. Um dos primeiros nomes a se impor nacionalmente foi o da bailarina carioca Eros Volúsia que teve a ousadia de dançar samba na ponta das 
sapatilhas e criou coreografias sobre ritmos brasileiros, através de um projeto chamado "Bailados brasileiros". A dança de Volúsia ganhava por vezes uma técnica e se firmava impondo o seu nome. Passando a se tornar referência e a ser adotada por muitos criadores. (PEREIRA, 2008, p. 53) Volúsia levou as danças nacionais folclóricas para os palcos dos teatros e de cassinos, assumindo a miscigenação da cultura brasileira; tornando-se mais tarde professora do Serviço Nacional de Teatro, no qual criou um curso de coreografia que formaria toda uma geração de bailarinos, dentre eles Hugo Bianchy. Ver figura 01

\subsection{A Fortaleza das primeiras informações sobre teatro e dança de Hugo Bianchy}

O cotidiano das grandes metrópoles nas décadas de 1950 e 1960 refletia uma enorme crença no mundo do progresso material, presente na automação da produção industrial e popularização do uso de automóveis e eletrodomésticos. No Brasil, esses reflexos eram sentidos mais diretamente na Capital Federal e em São Paulo. O acelerado aumento da população urbana e a consequente expansão das áreas construídas das cidades fizeram crescer especialmente as sedes administrativas de estados e regiões. Os hábitos cotidianos se transformavam numa velocidade sempre crescente, como se devessem acompanhar a automação da produção industrial. (SALES, 2001)

Em Fortaleza, essas transformações marcaram significativamente o campo da arte e da cultura no sentido de busca e renovação de novos hábitos e padrões estéticos. Fortaleza já concentrava as principais funções administrativas, econômicas e culturais do estado do Ceará, fato que favorecia um sentimento de otimismo responsável por um grande implemento da cultura artística e crescimento da cidade. Embalado por esta onda surgiram entidades culturais que envolviam atividades de literatura, cinema, rádio, teatro e dança. Dentre elas merecem destaque a Sociedade Cearense de Artes Plásticas (SCAP), responsável pela difusão da estética modernista e do reconhecimento de pintores e escultores como Aldemir Martins, Antônio Bandeira, Sérvulo Esmeraldo e Zenon Barreto, em nível nacional. (ESTRIGAS, 1983)

No campo da música tivemos a Pró-Arte, que teve como idealizador e fundador Gerardo Parente, contando com a colaboração de Orlando Leite, Carlos Sales, Leilah Carvalho e Odete Araújo, que mantinha vínculo direto com a Pró-Arte do Rio de Janeiro. Outra entidade que mobilizava o meio cultural era a Sociedade de Cultura Artística, fundada por Paurilo Barroso e Alberto Klein. Esta entidade foi responsável pela vinda de grandes nomes da música nacional e internacional aos palcos de Fortaleza. Enquanto os jovens talentos da terra aprimoravam suas habilidades musicais, a cidade recebia músicos consagrados, em saraus promovidos pelas sociedades artísticas.

A programação de rádio era responsável por parcela considerável do entretenimento e informação da população nos vários segmentos sociais de Fortaleza. Seguindo um padrão de audiência já experimentado no Sudeste, a programação era apresentada sob a forma de programas de auditório, com as mais diversas atrações artísticas populares e eruditas, rádio/teatro, noticiários e audições musicais executadas por músicos e orquestras locais, o que possibilitou o surgimento de um tipo de "profissionalização" no campo da arte e da cultura.

O cinema era outra modalidade de entretenimento resultante da difusão de novas tecnologias, que gradativamente ia sendo assimilado por todas as parcelas da população e 
trazendo novos hábitos culturais. Os dois grandes cinemas da cidade eram o Cine Diogo e o São Luiz, localizados próximos à Praça do Ferreira, local de encontro dos que faziam a vida cultural da cidade. Tal era a posição de destaque das exibições cinematográficas no cotidiano dos fortalezenses, que os passeios pelos quarteirões centrais da cidade, também chamados de "footing", se davam na Rua Guilherme Rocha e Barão do Rio Branco, próximos à Praça do Ferreira e aos cinemas. O mercado cinematográfico atendia a praticamente todas as faixas de poder aquisitivo da população. Vestir-se para ir a uma sessão do Cine Diogo e São Luiz exigia o mesmo rigor formal do comparecimento a um compromisso social ou da frequência a um baile. Para os rapazes, por exemplo o uso do paletó era obrigatório, ensejando situações constrangedoras para os cinéfilos de menor poder aquisitivo e, por outro lado, exigindo atitudes criativas por parte daqueles que não se incomodavam em burlar a norma.

Os amantes da "sétima arte" (era esta a expressão utilizada pelos cinéfilos da época) também se reuniam em torno de um clube chamado de Clube do Cinema de Fortaleza. Esse Clube foi criado por Antônio Girão Barroso e Darcy Costa, com o objetivo de discutir cinema e difundir a valorização do cinema de arte e contava com boa parte dos jovens que militavam nos movimentos e sociedades artísticas da época.

Paralelo a isso a produção do cinema americano ainda era a vedete do grande público, especialmente pela eficiência da publicidade em torno dos seus lançamentos, que eram anunciados com bastante antecedência. "Cantando na Chuva", que entrou em cartaz do Cine Diogo, em 1953, é um bom exemplo deste fenômeno. Divulgado com bastante antecedência pelas revistas especializadas, era ansiosamente esperado pelo público fortalezense, que já havia lido comentários elogiosos publicados pela imprensa especializada. "Cantando na Chuva" era um musical que possuía todos os ingredientes para agradar ao grande público da época. Apresentado em tecnicolor, era protagonizado por nomes bastante conhecidos na época, como Gene Kelly, Donald O'Connor e Debbie Reynolds. Foi o filme que marcou definitivamente a vida do então jovem Hugo Bianchy, para que mais tarde se tornasse bailarino e professor de dança.

Nesse contexto, os jovens amantes da dança em Fortaleza, enquanto aguardavam com ansiedade as raras apresentações de espetáculos de companhias que excursionavam pelo país, deleitavam-se com os filmes musicais. O bailarino Fred Astaire era a grande sensação dessas produções artísticas. Era uma espécie de modelo para os jovens amantes da dança. Ainda no início dos anos 1950, Gene Kelly, outro americano, passou a integrar essa galeria dos astros da dança. Na falta de escola de dança, os filmes musicais representavam praticamente a única possibilidade de um contato mais direto dos jovens de Fortaleza com o mundo da dança.

Hugo Bianchy era um desses jovens que se espelhavam nos movimentos de Fred Astaire e Gene Kelly e saía dançando pela cidade, algumas vezes até sendo visto como um lunático ou exibicionista. Em depoimento a um dos autores deste estudo, Hugo Bianchy afirma que foi assistindo aos musicais americanos que começou a sonhar com uma carreira de bailarino profissional.

Eu assistia os filmes de Fred Astaire e Gene Kelly, e depois saía pelas ruas do centro de Fortaleza pulando tudo, dançando e tentando imitar os passos de Gene Kelly e Fred Astaire. Antes de ir para o Rio de Janeiro estudar dança, eu pulava muito. Eu não conhecia a técnica de cair e dava saltos imensos. Meu primeiro contato com a dança foi, de fato, vendo os grandes bailarinos de Hollywood atuarem no cinema. (BIANCHY, 1999) 
Sonhando tornar-se bailarino profissional, Hugo Bianchy foi tentar a sorte no Rio de Janeiro, pela primeira vez no final de 1949 e lá permaneceu até 1951. Enfrentando dificuldades de toda sorte, resolveu retornar a Fortaleza e adiar por alguns anos o sonho de uma carreira na Capital Federal. No início, para sobreviver naquela cidade, Hugo trabalhou duro. Os primeiros trabalhos com dança foram em companhias de teatro de revista, integrando elenco de apoio a "shows" de artistas populares como Dercy Gonçalves, Grande Otelo, Vicente Celestino e Virgínia Lane.

Ao retornar a Fortaleza em 1951, Hugo Bianchy começou a ministrar aulas particulares de dança para "moças da sociedade", passando a dividir seu tempo entre a dança e o teatro. Em pouco tempo a dança se tornaria sua principal atividade e fonte de renda. $O$ teatro amador era uma espécie de complemento que o mantinha em contato com o público e o palco.

Em 1953, Hugo Bianchy montou seu primeiro espetáculo com alunos, apresentando-o no Ideal Clube, em Fortaleza. Tentando transformar a apresentação num grande acontecimento, projetou e mandou construir um palco no meio da piscina do Clube. Se à época um espetáculo de dança erudita com bailarinos locais já era uma novidade, imaginemos esse espetáculo apresentado num palco montado sobre uma piscina ao ar livre.

Outro grande momento da carreira de Hugo Biachy foi a coreografia da protofonia da ópera O Guarani, apresentada por ocasião da inauguração do salão nobre do Clube Náutico. A apresentação, de acordo com o bailarino, era uma espécie de "cavalo de batalha" da fase inicial de sua carreira. Eram dez minutos de dança, nos quais Hugo Bianchy se apresentava vestido apenas com uma espécie de tanga feita de penachos. Não fosse o grande talento do bailarino a plateia poderia ter ficado chocada com sua seminudez. Ver figura 02

Em fins de 1954, Hugo partiu novamente para o Rio de Janeiro, onde voltou a estudar e trabalhar com dança, retornando a Fortaleza somente em 1966. Durante a nova temporada na Capital Federal, Hugo aproveitou para estudar e aprimorar sua técnica. Eros Volúsia, professora do Serviço Nacional do Teatro, Tatiana Leskova, Denis Grey, David Dupret e Dina Nova (do Teatro Colon de Buenos Aires) foram seus professores.

O espetáculo de despedida de Hugo Bianchy foi um trabalho realizado com alunas, apresentado no Teatro José de Alencar. Um artigo anunciando o espetáculo nos oferece uma ideia do trabalho realizado por Hugo Bianchy em Fortaleza naquela primeira metade de década:

Acima de qualquer expectativa, Bianchy e seu Ballet transformarão o palco do velho teatro oficial num emotivo sonho de ballet clássico com bailados primorosos, capazes de empolgar a sensibilidade da nossa culta platéia." (...) 'O que esse moço está realizando em nossa capital é coisa admirável e até empolgante, não conhecendo eu aqui no Norte do país, no gênero um artista como ele, que tão bem soube interpretar o ballet clássico. (JORNAL O POVO, 1954)

No Rio de Janeiro, Hugo Bianchy trabalhou em companhias de teatro de revista, fez espetáculos solo e foi professor do Conservatório Nacional de Teatro. Retornou para trabalhar em Fortaleza nos anos 60, período em que montou sua academia, servindo de modelo para as 
demais escolas de dança da cidade. Além do trabalho de Hugo Bianchy, também merecem registro os cursos e as apresentações (algumas vezes chamadas de festival) de dança realizados pela Sociedade de Cultura Artística e pela Sociedade de Fotografia e Cinema, destacando-se como professora a jovem Alana Mara. Ver figura 03 e 04

\section{O PERCURSO METODOLÓGICO}

Os dados e as reflexões deste estudo tiveram como ponto de partida uma pesquisa sobre arte e cultura na cidade de Fortaleza, nos anos 1950, década em que Hugo Bianchy iniciou sua trajetória nos palcos. As primeiras coletas de dados foram realizadas através de matérias de jornal e, posteriormente, através de depoimentos orais gravados em áudio.

A inclusão dos procedimentos da História oral na investigação foi consequência da insuficiência de fontes escritas que dessem conta de dados necessários para abrir as discussões e análises dos processos de formação de Hugo Bianchy. Trata-se de um procedimento da história contemporânea surgida em meados do século XX e consiste na realização de entrevistas, isto é, coleta de depoimentos gravados com sujeitos que participaram ou testemunharam acontecimentos e conjunturas do passado e do presente, que constituem objeto da investigação. (ALBERTI, 2010, p. 155)

A coleta do depoimento foi realizada por meio de entrevista temática, em que se buscou complementar informações contidas nos documentos escritos, evidenciando dados que ainda não haviam sido documentados, especialmente os dados presentes nas matérias de jornal. Meihy (1996, p.13), ao defender a história oral como método, diz tratar-se de um "recurso moderno usado para a elaboração de documentos, arquivamento e estudos referentes à vida da pessoa" característica que para o presente estudo foi primordial. Para obter os resultados desejados com os depoimentos orais, os trabalhos seguiram três etapas: a preparação das entrevistas, sua realização e seu tratamento. (ALBERTI, 2010, p. 171)

Os documentos escritos consultados com informações oficiais sobre a trajetória de Hugo Bianchy foram prioritariamente matérias do Jornal O Povo. Além das fontes escritas também foram consultadas as iconográficas, nas quais se destacam fotografias de acervos pessoais, que retratam o professor e bailarino atuando em espetáculos e ministrando aulas.

No que se refere ao tratamento dos dados, foram analisados depoimentos coletados através das transcrições dos textos. Os dados básicos sobre processos formativos foram organizados em ordem cronológica, visando facilitar os possíveis cruzamentos com as demais fontes. Sobre esses procedimentos de pesquisa, nos quais se utiliza os instrumentos e procedimentos da história oral, Alberti (2010, p. 187) recomenda a comparação dos conteúdos das entrevistas com os demais documentos, afirmando que "às vezes há um deslocamento temporal ou de sentido que permite ao pesquisador verificar como a memória sobre o passado vai se constituindo no grupo".

Nesse sentido, a orientação deste estudo segue os paradigmas da Nova História, para a qual a noção de documento foi revista e ampliada em função dos novos objetos e temáticas. Se antes o historiador dispunha apenas das fontes escritas, com a ampliação do conceito de documento, suas fontes e possibilidades foram radicalmente ampliadas e revistas. Tratando desta problemática assim se expressa Febvre (1985, p.249): 
[...] A história faz-se com documentos escritos, sem dúvida. Quando eles existem. Mas ela pode fazer-se, ela deve fazer-se sem documentos escritos, se os não houver. Com tudo o que o engenho do historiador pode permitir-lhe utilizar para fabricar o seu mel, à falta de flores habituais. Portanto, com palavras. Com signos. Com paisagens e telhas. Com formas de cultivo e ervas daninhas. Com eclipses da lua e cangas de bois. Com exames de pedras por geólogos e análises de espadas de metal por químicos. Numa palavra, com tudo aquilo que pertence ao homem, depende do homem, serve o homem, exprime o homem, significa a presença, a atividade, os gostos e as maneiras de ser do homem [...].

Por fim, a escolha de procedimentos que envolvem como fontes principais as matérias de jornal e depoimento oral caracteriza a abordagem do presente estudo, como uma investigação no âmbito dos pressupostos teórico-metodológicos da Nova História Cultural (NHC). A NHC trata das heranças de artefatos, bens, processos técnicos, ideias, hábitos e valores, configurando-se como um ramo da história que trata dos estudos culturais. (BURKE, 2005, p. 43)

\section{RESULTADOS E DISCUSSÕES}

\subsection{Hugo Bianchy: dança da elite e genealogia das academias em Fortaleza}

Enquanto na Capital Federal Eros Volúsia e outros nomes da dança erudita já haviam despontado desde a década de 1940, em Fortaleza nos anos de 1950, os eventos exclusivos de dança cênica ainda eram bastante raros e mesmo aqueles de danças folclóricas ou populares quando aconteciam eram parte integrante de "shows" e "festivais" de música.

Hugo Bianchy é apontado como um dos artistas docentes pioneiros na formação da dança cênica em Fortaleza, embora não possua uma "formação completa" de balé clássico, técnica na qual se tornou professor. Na década de 1960, iniciou a oferta de aulas de balé clássico, fundando uma das primeiras escolas de dança da cidade, a academia Eros Volúsia (título dado em homenagem à sua mestra em dança no Rio de Janeiro).

Quanto à atuação como professor, Hugo Bianchy aponta que a sua formação como bailarino, que foi muito rígida, revelou-se decisiva para sua transição como professor:

Eu não fiz um curso para ser professor de dança, e sim uma formação como artista. Fiz aula com grandes nomes da dança brasileira e a Eros Volúsia foi minha mestra. Ah! Eu era um professor violento. Bailarino tem que sacrificar alguma coisa. Eu usava uma varinha e mandava as meninas fazerem battement-tendu e passava com uma varinha e dizia: estica a perna, o pé, levanta a perna, e se elas não faziam isso eu tacava a varinha. No Rio, onde me formei, a coisa era mais séria. Tem que ter alma de artista. Talvez por isso eu fosse tão rígido. Por acreditar que tínhamos que levar a sério. (BIANCHY, 2012)

Notamos na fala de Hugo Bianchy que não havia na época uma preocupação com a formação do professor de dança. A sua formação artística era o que alicerçava a condição para 
ser professor. Percebemos através do seu dizer que sua arte estava impregnada do sacrifício, resvalando mais tarde em sua metodologia como formador.

A rigidez e autoridade na sua aula de dança configurava uma prática educativa centrada no professor, na qual o aluno era mero reprodutor; fundamentada em uma pedagogia tradicional citada no Século $X X$, em que o aluno aprende pela transmissão do conhecimento através do professor.

Observamos com estas análises que o professor como formador desta linguagem necessita refletir constantemente sobre suas escolhas e as consequências. Elementos da dança, tais como: corpo e movimento, fatores e qualidade de movimento e a relação tempo e espaço podem auxiliar o educador de dança. Associando isto à memorização de gestos, improvisações e criações expressivas, propiciamos uma multiplicidade em uma aula desta área de conhecimento.

Hugo Bianchy tornou-se o grande responsável por uma linhagem das academias de dança de Fortaleza, visto que grande parte das gestoras destas instituições foram alunas dele. Quando iniciou suas atividades de ensino de dança no ano de 1965, os alunos de Hugo eram na sua maioria as senhoritas da "sociedade" de Fortaleza, pois naquela época as aulas de dança eram destinadas ao público que pudesse pagar. Do ponto de vista da metodologia, pode-se afirmar que o artista-professor aproximava o seu método de trabalho do modelo tradicional de ensino da dança clássica, que se caracteriza por uma concepção reprodutivista, inspirada em sua formação no Serviço Nacional de Teatro no Rio de Janeiro. Esse é um método que ainda vem sendo reproduzido na atualidade em algumas academias.

Com as discussões sobre o ensino de arte e, especialmente, com o movimento da ArteEducação na década de 1980, artistas e professores passaram a discutir formação e metodologias do ensino de Arte. As discussões geraram uma série de reivindicações, que resultaram em novas políticas e uma redefinição das finalidades do ensino de Arte.

No método tradicional de ensino não há espaço para a dança como área de conhecimento. Como afirma Marques (2007):

[...] Corpos nesta situação de ensino-aprendizado são continuamente ameaçados caso as regras não sejam estritamente seguidas: contracenam com o fantasma da censura, da perda de papéis de destaque [...] As redes de relações educacionais implícitas em processos de criação semelhantes a este não raramente se transformam em redes de poder autoritário e de dominação que não permitem a construção do conhecimento propriamente dita. (MARQUES, 2007, p. 106)

A dança incita a uma reinvenção do corpo, no sentido de que para criar/lecionar algo neste lugar proposto há a necessidade implícita de um aprofundamento das potencialidades do corpo - que é também objeto de estudo da dança. Na subjetividade e nas relações estabelece-se essa criação. Sob esse aspecto, o ensino das academias que aqui foi reproduzido através do trabalho de Hugo Bianchy, pouco se preocupou com os aspectos criativos da dança, privilegiando a execução e repetição de movimentos.

Faltou ao processo de ensino de dança uma reflexão mais ampla que contemplasse duas realidades: um aprofundamento do que é o corpo (em termos teóricos e práticos) e a utilização da dança na promoção do conhecimento para proporcionar uma "disseminação de sentidos," pelo subsídio de ferramentas possíveis e concretas na consecução de uma proposta em dança. 
Ou seja, articular a dança não só como arte para executar movimentos (a ideia do movimento pelo movimento), mas como uma arte que é conhecimento a partir do que é produzido no corpo.

Em Fortaleza, observamos que a genealogia das academias de dança, iniciada por Hugo Bianchy na década de 1960, explicitadas em uma concepção de dança clássica idealizada em grandes espetáculos ou musicais, dificultou uma concepção desta linguagem artística como área de conhecimento e formação. Embora ações formativas em dança na nossa cidade venham delineando-se, a década acima citada disseminou e fomentou uma dança que privilegia modelos reprodutivistas que ainda predominam nas composições estéticas das academias de Fortaleza.

\section{CONSIDERAÇÕES FINAIS}

O estudo mostra que a formação em dança na cidade de Fortaleza tem como marco a década de 1960 quando Hugo Bianchy coloca em funcionamento sua academia de dança. A participação desse artista/educador no cenário da dança cearense delineia-se em um modo próprio de pensar e fazer formação nesta linguagem artística. Evidenciamos uma disseminação do seu fazer pedagógico, com características advindas de modelos tradicionalistas de ensino de artes. Nota-se ainda que não existia uma preocupação com a formação do professor de dança nas décadas aqui estudadas, e sim, com a formação do bailarino.

Embora a formação de Hugo Bianchy tenha sido eclética (teatro, circo, música e dança), a sua contribuição como professor está circunscrita ao que se considera "dança clássica". Destacase ainda na discussão, o fato da implantação tardia do balé clássico entre nós. Os anos 1960 - no campo das demais linguagens artísticas, representou a efervescência do movimento de modernização do meio artístico de Fortaleza. Outra contradição da história da dança clássica em Fortaleza é o fato de ter sido introduzida por um bailarino professor que teve uma formação clássica tardia e eclética.

Contradições a parte, o pioneirismo das ações de Hugo Biachy e o seu papel na formação do meio artístico da dança em Fortaleza o colocam num lugar de destaque, como um modelo a ser seguido por mais de uma geração de bailarino.

A análise crítica que se buscou nesta abordagem, longe de desconhecer o papel pioneiro do bailarino professor pretende, sobretudo, reconhecer a sua contribuição na qual estão presentes erros, acertos e avanços, dentro de um contexto histórico e cultural da década de 1960.

Esta reflexão evidencia a necessidade de discussão acerca da formação docente em dança em Fortaleza, para que se possa compreender, numa perspectiva histórica, que ensino de dança tem sido adotado. Será que as formações da atualidade apenas reforçam o modelo histórico aqui implantado por Hugo Bianchy ou já caminham em outras direções? Nossa função como historiadores da educação e professores de arte é fornecer elementos para que se estabeleçam novas discussões, bem como que estas possam lançar luz sobre os processos de ensino, aprendizagem e produção em arte. 


\section{REFERÊNCIAS}

ALBERTI, V. (2010). Histórias dentro da História. En: PINSKY, B. C. Fontes Históricas. 2. ed. São Paulo: Contexto.

BIANCHY, H. (1999). Hugo Alves Mesquita. Bailarino e professor de dança, nasceu em Fortaleza em 29/04/1926. Entrevistas concedida a José Albio Moreira de Sales. Fortaleza, 29/07/1999.

BIANCHY, H. (2012). Hugo Alves Mesquita. Bailarino e professor de dança, nasceu em Fortaleza em 29/04/1926. Entrevista concedida ao Projeto Memória Viva da Licenciatura em Dança da Universidade federal do Ceará (UFC.) Fortaleza, 06/06/2012.

BURKE, P. (2005). O que é história cultural? Tradução de Sérgio Góes de Paula. Rio de Janeiro: Jorge Zahar.

BOURDIEU, P. (2010). As regras da arte. 2. ed. Tradução de Maria Lucia Machado. São Paulo: Companhia das Letras.

ESTRIGAS, N. de B. F. (1983). A fase renovadora na arte cearense. Fortaleza. Edições Universidade Federal do Ceará.

FEBVRE, L. (1985). Combates pela História. 2. ed. Lisboa: Editorial Presença Ltda.

JORNAL O POVO. (1954). Fortaleza, 30/11/1954.

KASSING, G. (2007) History of Dance, an Interactive Arts Approach. Illinois/Champaign: Human Kinetics.

MARQUES, I. (2007). Ensino de Dança hoje: textos e contextos. 4. ed. São Paulo: Cortez.

MENDES, M. G. (2001). A dança. 2 ed. São Paulo: Ática. Série princípios.

MEIHY, J. C. S. B. (1996). Manual de História oral. São Paulo: Loyola.

MEYER, S., NORA, S. \& PEREIRA, R. (2008). (Orgs.) Seminários de Dança - Histórias em movimento: Biografias e registros em dança. Caxias do Sul, RS: Lorigraf.

SALES, J. A. M. (2001). Fortaleza Anos 50: uma História da Arte como História da Cidade. Recife. Tese de Doutorado defendida no Programa de Pós-Graduação em História da Universidade Federal de Pernambuco - UFPE. 


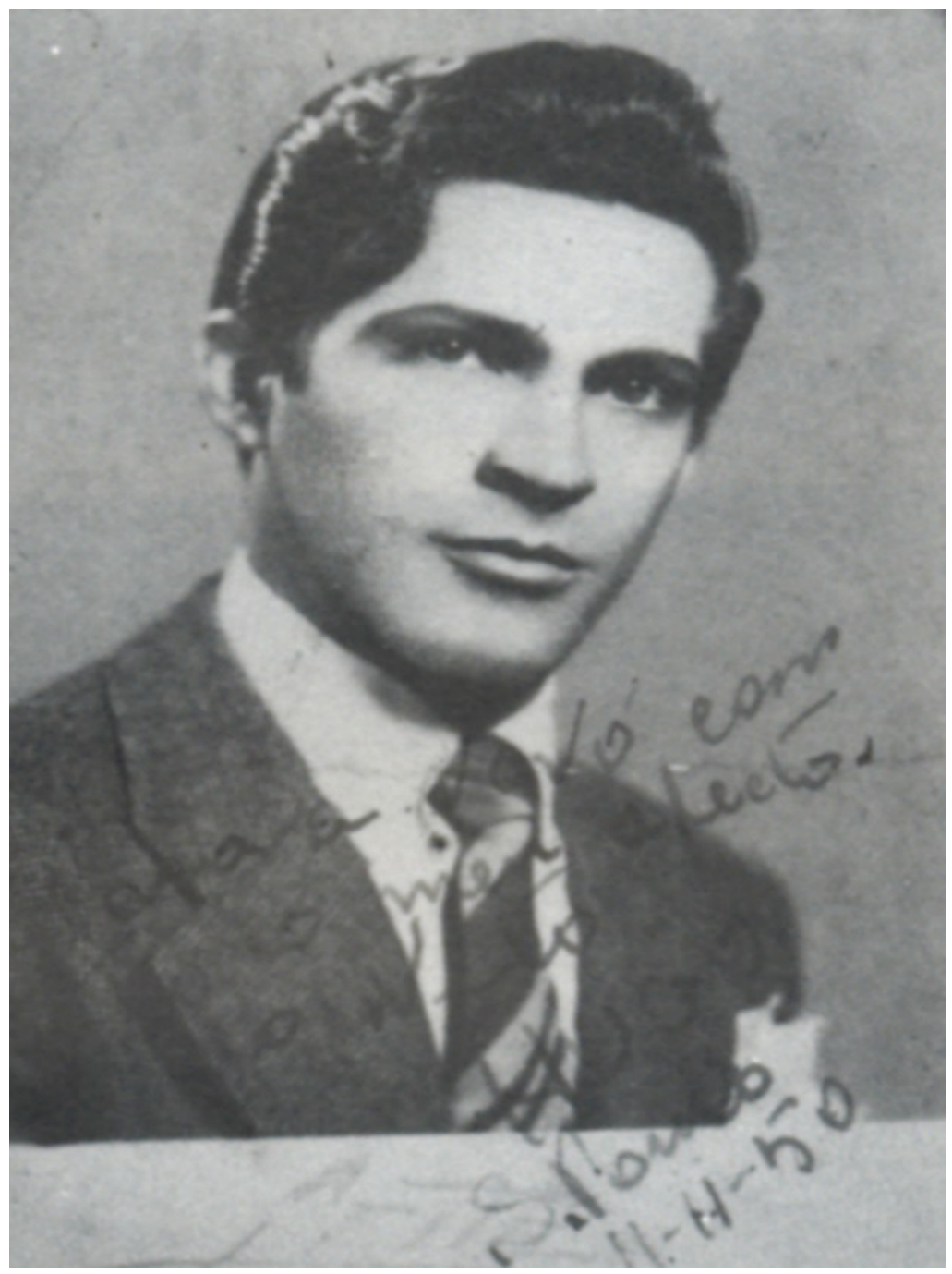

Figura 1 - Hugo Bianchy, foto dedicada a avó - 1950, em São Paulo Fonte: Arquivo Projeto Memória Viva Licenciatura em Dança- UFC 


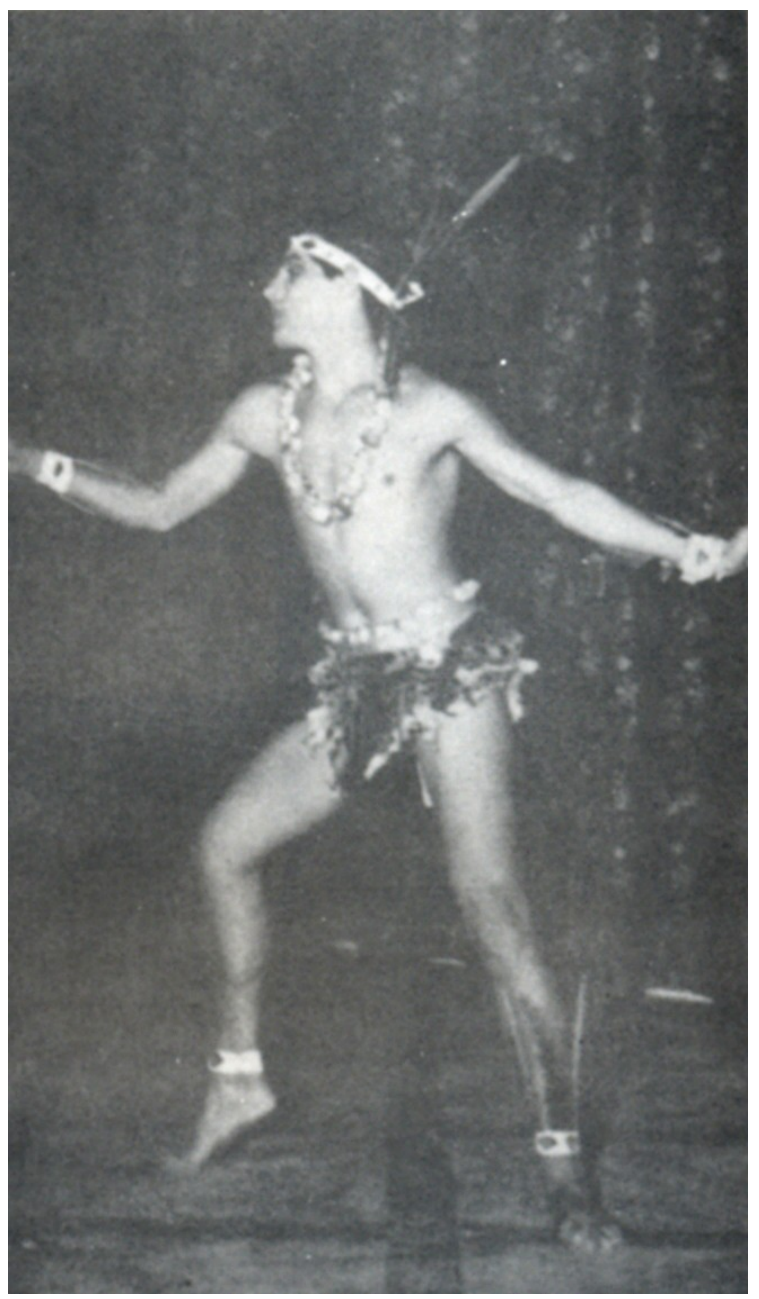

Figura 2 - Hugo Bianchy em “O Guarani”, 1965

Fonte: Arquivo Projeto Memória Viva Licenciatura em Dança- UFC

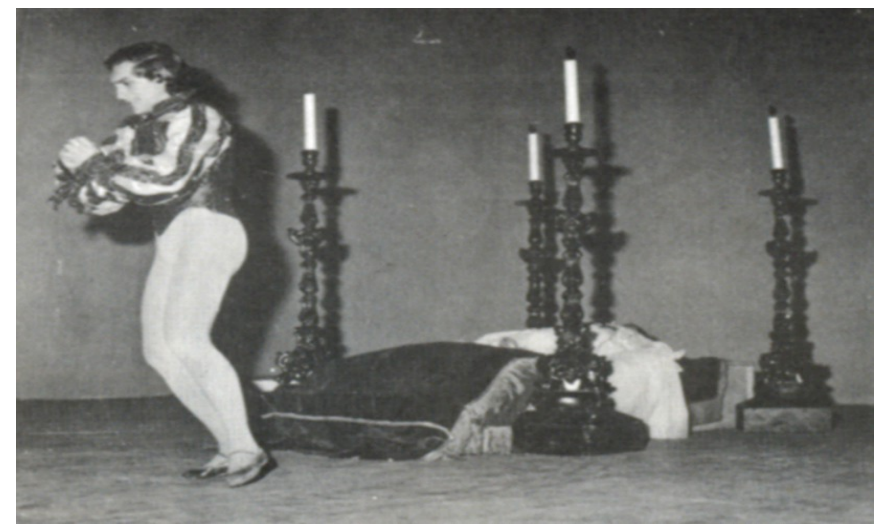

Figura 3 - Hugo Bianchy em "Romeu e Julieta"

Fonte: Arquivo Projeto Memória Viva Licenciatura em Dança- UFC 


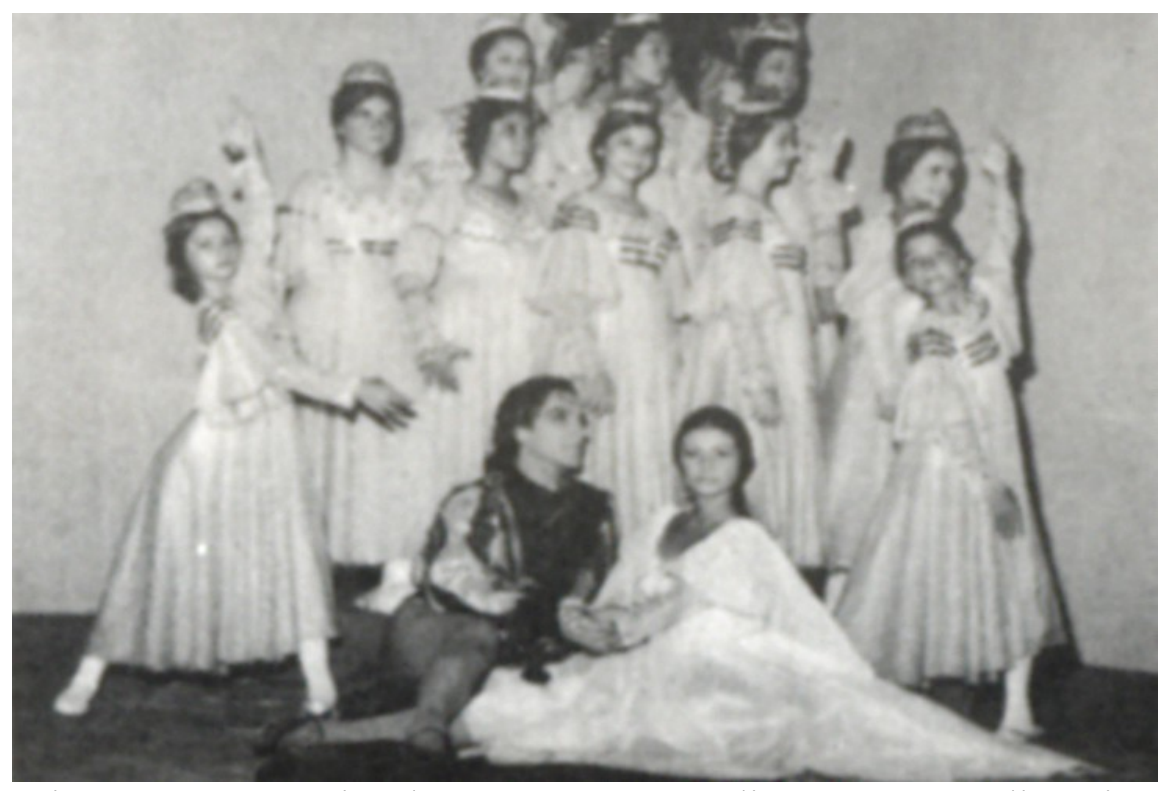

Figura 4 - Hugo Bianchy em "Romeu e Julieta", com Cecília Leite Fonte: Arquivo Projeto Memória Viva Licenciatura em Dança- UFC 